\title{
Zjazd Królów. Zbigniew Herbert w polskim Paryżu Anno Domini 1967
}

Andrzej Franaszek 


\section{Zjazd Królów. Zbigniew Herbert w polskim Paryżu Anno Domini 1967}

Andrzej Franaszek
Tekst jest fragmentem książki Andrzeja Franaszka Herbert. Biografia, która ukaże się w maju 2018 r. nakładem wydawnictwa Znak.

TEKSTY DRUGIE 2017, NR 4, S. 376-400

DOI: $10.18318 /$ td.2017.4.22

Płaciłem. Za wszystko. Ciałem moim i duszą moją.

Za niebo, za wiatr, za strofę, za uśmiech panien, za tych dwoje rąk nawet okrutnych, które nie dają mi na dno iść. Co prawda, procenty lichwiarskie tak urosły, że spłacę nie wcześniej aż na Sądzie Ostatecznym... ${ }^{1}$

- pisał Aleksander Wat, który potrafił tworzyć poezję wprost z materii cielesnego bólu, choroby przynoszącej ataki przez niego samego porównywane do przypalania skóry ogniem. Jak wiadomo, na początku lat 50. zaczął chorować na - tak to określa medyczny leksykon - zespół Wallenberga, wyjeżdżał na leczenie do Francji, zmagał się z falami cierpienia, upatrując w nim czasem kary za młodzieńczy związek z komunizmem, rzec można: podpisanie cyrografu. W czasie jego pobytu w Berkeley (gdy w rozmowach z Miłoszem powstawał Mój wiek) Zbigniew Herbert słał do Wata podnoszące na duchu zapewnienia,

1 A. Wat Buchalteria, w tegoż Poezje, opr. A. Micińska, J. Zieliński, Warszawa 1997, s. 7 .
Andrzej Franaszek

- krytyk literacki, redaktor "Tygodnika Powszechnego", pracownik Uniwersytetu Pedagogicznego w Krakowie. Autor książki Miłosz. Biografia (2011), za którą otrzymał m.in. Nagrodę Fundacji im. Kościelskich, Nagrodę Nike Czytelników "Gazety Wyborczej," Nagrodę im. Kazimierza Wyki oraz Nagrodę MKiDN. Autor książek Ciemne źródło. Esej o cierpieniu w twórczości Zbigniewa Herberta oraz Przepustka z piekła. 44 szkice o literaturze i przygodach duszy. Kontakt: franaszek@ pro.onet.pl 
że czeka na nowe wiersze, do których powstania może się przyczynić kalifornijski klimat, i deklarował: ,jestem głęboko przekonany, że w ostatecznym bilansie tak zwana literatura emigracyjna przeważy nad produkcją krajową zupełnie jak w czasach Adama, Juliusza i Cypriana"2 . Wróciwszy do Europy, pod koniec roku 1966, podczas chwilowego polepszenia, Watowie wyjadą na Majorkę, tam emigrant Aleksander napisze wspaniały, cytowany przed chwilą wiersz Buchalteria, którego kolejne linie brzmią: „I płynąc pod czarnym sklepieniem / i śledząc odbicie, na czarnych wodach, przewoźnika, / jego wysiłków, tak regularnych, rozmachu czarnych wioseł, / myślę ze ściskiem serca o bólach, które mnie jeszcze czekają".

Już wkrótce ból ten okaże się w dosłowny sposób nie do wytrzymania, przyniesie poecie decyzję o samobójstwie, jednak na razie, latem 1966 roku oboje Watowie w Paryżu z przyjemnością obserwowali, jak do kawalerki w ich sąsiedztwie wprowadza się Herbert, który zresztą jeszcze z Wiednia dziękował Aleksandrowi za „dopuszczenie mnie do przyjaźni. W serca mego starej kamienicy masz już od dawna apartament $\mathrm{z}$ widokiem na drzewa i kwiaty"3. Poszukiwania Katarzyny Dzieduszyckiej, wkrótce żony autora Napisu, przyniosły bowiem wreszcie rezultat, aczkolwiek udało jej się znaleźć locum nie w samym Paryżu (jak chciał poeta), a na jego dość odległym przedmieściu - Antony, w niedawno oddanych do użytku blokach, jeszcze bez drzew i kwiatów wokół, gdzie mieszkali głównie portugalscy imigranci, podróż do centrum trwała długo, ale było oczywiście taniej. W ten sposób na kopertach z listami mógł teraz Herbert podawać adres „3, square Gabriel Fauré”, tuż obok mieściły się inne muzykalne place - imienia Debussy'ego i Couperina. „Zaczęło się bardzo dobrze, bo niesłychanie przypadli sobie do gustu. Często odwiedzał Wata, lubili ze sobą rozmawiać"4 - wspominała później Katarzyna, sam zaś poeta, z nieodmienną uważnością rozglądał się wokół i zdawał relację swemu niemieckiemu tłumaczowi, Karlowi Dedeciusowi: „usiadłem na miejscu, wypuściłem z siebie przeciągłe uff i poszedłem spać, z wolna chyba dojdę tu do siebie. [...] Kupiłem czajnik, patelnię, jaja i kiełbasę z czosnkiem, po której boli brzuch, ale jest bardzo dobra. Może przez jakieś dwa miesiące uda mi się odegrać rolę człowieka osiadłego. Moimi sąsiadkami są Niemki

2 List Z. Herberta do A. Wata, bm. [Paryż], bd. [grudzień 1963-styczeń 1964], w: A. Wat Korespondencja, cz. II, opr. A. Kowalczykowa, Czytelnik, Warszawa 2005, s. 92.

3 List Z. Herberta do A. Wata, Wiedeń, 2 lutego 1966, w: A. Wat Korespondencja, cz. II, s. 93.

4 K. Herbertowa Ze Zbigniewem Herbertem mój życiorys, w: Wierność. Wspomnienia o Zbigniewie Herbercie, opr. A. Romaniuk, PWN, Warszawa 2014, s. 138. 
z Hamburga (jedna bardzo ładna), pożyczyły mi butlę z gazem, tak więc piję rano gorącą herbatę (luksus!) i współpraca rozwija się"”.

Praca samodzielna szła mu natomiast tak sobie, walczył z ostatecznie nieukończoną sztuką Alibi, zresztą zwykle nie był z siebie zadowolony, choć przecież jesienią w pokoiku zaczęły się pojawiać „małe górki papieru na stole, pod szafą i lustrem"6. Pod koniec grudnia, a więc po powrocie z berlińskiego festiwalu, który przyniósł mu olbrzymi sukces, wysłał plik świątecznych korespondencji, wśród nich list do Jerzego Zawieyskiego, opowiadając: „największą frajdę, jaką tu miałem, to był Vermeer”, i raz jeszcze podkreślając, że „jeśli sztuka nie będzie kontemplacją, pokornym zagapieniem się w przedmioty i dalej - zginie jak pies (a raczej jak suka). Amen"7.

\section{***}

Jeśli w Niemczech Herbert stawał się wtedy poetycką gwiazdą, nad Sekwaną musiał na nowo przywyknąć do anonimowości przybysza z nieledwie egzotycznego kraju, przekładów jego wierszy na francuski było mało, zresztą polska poezja bodaj nigdy nie potrafiła dobrze się w tym języku zadomowić, a poza tym Francuzi, inaczej niż Niemcy, w większości nie przejawiali żywiołowego zainteresowania innymi kulturami ${ }^{8}$. W roku 1967 do Paryża

5 List Z. Herberta do K. Dedeciusa, Antony, 4 lipca 1966; Karl Dedecius Archiv der Europa-Universität Viadrina Frankfurt (Oder) / Archiwum Karla Dedeciusa przy Collegium Polonicum w Słubicach; Nachlass Karl Dedecius / Spuścizna po Karlu Dedeciusie; dalej: ZHKD.

6 List Z. Herberta do J. Hartwig i A. Międzyrzeckiego, Antony, 9 listopada 1966; w: J. Hartwig, A. Międzyrzecki, K. i Z. Herbertowie Korespondencja, opr. M. Zagańczyk, Zeszyty Literackie, Warszawa 2012, s. 28; dalej: ZHHM.

7 List Z. Herberta do J. Zawieyskiego, Antony, 23 grudnia 1966; w: Z. Herbert, J. Zawieyski Korespondencja 1949-1967, opr. P. Kądziela, Więź, Warszawa 2002, s. 144; dalej: ZHJZ.

8 Pomijając antologię Konstantego Jeleńskiego, Zbigniew Herbert nie miał szczęścia do publikacji swych wierszy w języku francuskim. Na przełomie lat 60. i 70. o wydanie wyboru jego poezji starał się Luc de Goustine, redaktor Éditions du Seuil. Pisarz miał jednak zastrzeżenia do tłumaczeń autorstwa Allana Koski, nad tomem pracować mieli Teresa Dzieduszycka oraz Jerzy Lisowski, sprawa przeciągała się, aż de Goustine odszedł z wydawnictwa w roku 1972. Pierwszy samodzielny tom Herberta ukazał się dopiero w roku 1990, książkę Monsieur Cogito et autres poèmes w przekładach Alfreda Sproede opublikowało Éditions Fayard. Sam poeta był w pełni zadowolony bodaj jedynie z tomu "Redresse-toi et va", który przygotował i przełożył Jacques Burko, wydało zaś Editions de la Différence w roku 1995. Niewątpliwie przełomowe dla francuskiej recepcji Herberta były lata 2011-2013, kiedy to wydawnictwo Le Bruit du Temps opublikowało trzy tomy jego poezji zebranych w tłumaczeniu Brigitte Gautier. 
przyjechali Julian Przyboś i Wisława Szymborska, odwiedzali zadomowionego tu Jana Brzękowskiego, na jednym ze zdjęć widać nawet, jak poetka $\mathrm{z}$ wdziękiem siedzi na eleganckim foteliku, w jednej ręce trzymając papierosa, w drugiej - kieliszek koniaku, a w dodatku jeszcze flankowana jest przez ubranych w nienaganne garnitury Przybosia i Herberta. Wizycie tej zawdzięczamy opowieść przyszłej noblistki, mówiącą tyleż o charakterze autora Barbarzyńcy w ogrodzie, co o typowej postawie galijskiego literata. Otóż:

Brzękowski zaprosił nas do siebie. [...] Był on odrobinkę snobem i zaprosił pewnego francuskiego pisarza [...], który dostał Prix Goncourt. [...] i ten pan [...] wodził okiem po nas, Słowianach, którym trzeba zrobić grzeczność. I w tym momencie rozlega się dzwonek, przychodzi Zbyszek [...] Otwiera ramiona i mówi: „No, nareszcie mogę pana poznać, dotknąć, porozmawiać chwilę, no, nareszcie, jestem taki szczęśliwy! Czy mogę tutaj usiąść u pana kolan?". Ten, zadowolony, mówi, że proszę bardzo, oczywiście. Zbyszek układa się u jego stóp w uniżonej pozie i mówi: „My, Słowianie, musimy się tutaj wszystkiego uczyć, my nic nie wiemy. Wy całą literaturę klasyczną, cały świat łaciński macie we krwi, a my musimy z takim trudem do tego wszystkiego dochodzić...". Tamten kiwa ze zrozumieniem głową. A Zbyszek kontynuuje: „Ja się dopiero tutaj dowiedziałem niedawno, że Hera była żoną Jowisza, a Junona była żoną Zeusa". Na to pan Prix Goncourt: „Nie, to było odwrotnie, ale to nic nie szkodzi, bo te boginie i ci bogowie to są właściwie jednakowi, to jest to samo właściwie". I w tym momencie Zbyszek [...] z błyskiem w oku mówi: „No, nie jest to takie pewne. Przecież Rzymianie brali swoje wierzenia nie bezpośrednio od Greków, ale od ludów zamieszkujących półwysep, a przede wszystkim od Etrusków. I wszystkie imiona tych bogów są etruskie. Również ich atrybuty są trochę inne - ciągnie Herbert. - Zresztą pisał o tym ten a ten" - i tutaj wymienia całą litanię jakichś profesorów [...]. I ten pan Prix Goncourt spurpurowiał, bo zobaczył, że robi się z niego balona. 9

Choć tego rodzaju prowokacje musiały być imponująco śmieszne, to na co dzień klimat lekceważenia, a w każdym razie braku zainteresowania, z jakim

9 Cyt. za: J. Illg Mój Znak. O noblistach, kabaretach, przyjaźniach, ksiq̨żkach, kobietach, Znak, Kraków 2009, s. 135 in. 
zderzali się polscy emigranci czy goście w Paryżu, kiedy w latach 6o. minęła już moda na Polskę, musiał rodzić frustrację. Ale naturalnie od reguły były wyjątki, zdarzali się pisarze i intelektualiści o zupełnie innej postawie. We wspomnieniach Julii Hartwig pojawia się zatem postać André Frénauda, poety urodzonego na początku stulecia, który w roku 1930 był lektorem na Uniwersytecie we Lwowie i odtąd już zawsze „Polska była mu bardzo bliska”" Znał go również autor Struny światła, a nawet zdecydował się redagować jego tom dla polskiego wydawnictwa, po części ze względów zarobkowych, z pewnością jednak także wiedziony przyjacielskimi uczuciami, zresztą w liście do Międzyrzeckiego, który wspomagał go w tym przedsięwzięciu, przyznawał, że „Frenoszczaka” - „bardzo lubi”"1. Z początkiem roku 1967 w pokoiku w Antony wybierał więc i przekładał wiersze, które złożą się na opublikowany przez PIW tom Nie ma raju ${ }^{12}$. Tłumaczami są tutaj także Międzyrzecki i Iwaszkiewicz, sam zaś Herbert przełożył siedemnaście wierszy, a więc zdecydowanie więcej niż utworów jakiegokolwiek innego - tłumaczonego przez siebie poety.

Oprócz Frénaud na pierwszy plan tej niewielkiej konstelacji wysuwa się Pierre Emmanuel, poeta i tłumacz, by jeszcze raz posłużyć się opowieścią Julii Hartwig: „człowiek wielkiej szlachetności, oddany w przyjaźni, mądry, wykształcony. Pamiętam jak przyjechałam do Paryża, [...] zadzwoniłam od razu do Pierre'a Emmanuela. On mnie zaprosił do siebie, oczywiście wypytywał, jak jest w Polsce. I trudno w to uwierzyć - on słuchał i się rozpłakał. A to nie był ktoś taki kto się roztkliwia, tylko on miał taką siłę współczucia"13. Emmanuel przyjaźnił się z Jeleńskim, współpracował też z Kongresem Wolności Kultury, gdy doszło do skandalu dotyczącego źródeł jego finansowania, razem z Kotem założyli Fundację na rzecz Europejskiej Wzajemnej Pomocy Intelektualnej, z której pomocy skorzystało wielu polskich pisarzy. I znów, podobnie jak w przypadku Frénaud, Herbert i Międzyrzecki będą tłumaczyć wiersze Emmanuela, w archiwum autora Napisu znajdziemy podziękowania autora z uwagą, że przekład chwalił Jeleński ${ }^{14}$. Kot zapewne czytał tłumaczenie

Rozmowa autora książki z Julią Hartwig, Warszawa, 14 listopada 2013 r.

List Z. Herberta do A. Międzyrzeckiego, Antony, 24 września 1966; ZHHM, 21.

A. Frénaud Nie ma raju, opr. Z. Herbert, PIW, Warszawa 1968.

Rozmowa autora książki z Julią Hartwig, Warszawa, 14 listopada 2013 r.

Por.: List P. Emmanuela do Z. Herberta, Paryż, 8 lutego 1968; Archiwum Zbigniewa Herberta, Biblioteka Narodowa, Zakład Rękopisów, Warszawa, Akc. 18005, t. 22; dalej: AZH. 
fragmentów poematu Poeta szalony, które w roku 1969 opublikował „Tygodnik Powszechny", linie mówiące zresztą o zamknięciu, izolacji, oczekiwaniu śmierci.

Hartwig, Międzyrzecki, Frénaud, Emmanuel, Jeleński - taki bodaj, jak widać niewielki, był krąg przyjaciół łączących wtedy Herberta z francuskim życiem literackim. Można tu jeszcze dopisać Thérèse Douchy, czyli Teresę Dzieduszycką, siostrę Katarzyny, tłumaczkę, autorkę przekładów także wierszy Herberta. Co prawda sam autor nie był do końca pewny rezultatu jej pracy, jeszcze z początkiem lat 70. poprosił Frénaud i Rogera Caillois o przeglądanie tych tłumaczeńn ${ }^{15}$. Przy czym do znanego krytyka, historyka idei zwracał się dlatego, że Caillois pomógł znaleźć francuski kształt Trenowi Fortynbrasa i Powrotowi prokonsula, gdy były one publikowane w przygotowanej przez Jeleńskiego antologii.

Dzieło to, pięciusetstronicowy tom prezentujący historię polskiego wiersza, a zatytułowany po prostu Anthologie de la poésie polonaise, opublikowało wydawnictwo Seuil w roku 1965. Historia jego powstawania jest jednak dłuższa i bodaj od samego początku uczestniczył w niej po trosze również Herbert. W każdym razie już podczas pierwszego pobytu w Paryżu dawał znać rodzicom, że pomaga w układaniu takiego dzieła, wtedy zresztą mógł jeszcze stwierdzić, że „zainteresowanie literaturą polską jest istotnie duże i niebanalne (choć trochę koniunkturalne)"16. Z tymi pracami, a może także z powstającymi w podobnym czasie antologiami Dedeciusa i Miłosza, wiążą się uwagi w notesach pisarza ${ }^{17}$ - notki biograficzne poetów, przepisane wiersze, od Sępa-Szarzyńskiego poczynając, na Miłoszu i Gajcym kończąc, na ich podstawie można by się pokusić o ułożenie wyboru ulubionych wierszy samego Herberta, zresztą jeden z notesów ma na okładce tytuł „Wiersze które lubię"18. System pracy, jaki przyjął Jeleński, opierał się po części na przygotowaniu tłumaczeń dosłownych, czyli tzw. rybek, dzięki nim ostateczny kształt wierszom nadawali pisarze francuscy, choćby Yves Bonnefoy czy Jean Cassou. Herbert należał przy tym do poetów najliczniej reprezentowanych, zaś czytelnik mógł przeczytać we wstępie Miłosza, że „jego poezja ostra, krystaliczna,

15 Por.: AZH, Akc. 18005 , t. 13.

List Z. Herberta do Rodziców, Paryż, 7 listopada 1958, w: Z. Herbert Korespondencja rodzinna, opr. H. Herbert-Żebrowska, A. Kramkowska-Dąbrowska, Gaudium, Lublin 2008, s. 80; dalej: ZHKR. 
intelektualna wydaje się działać samą kwintesencją, dążąc w swoich skrótach aż do dna doświadczenia zbiorowego, [...] przezwyciężając paraliż woli spowodowany przez pokusę absurdu"19. Inna już rzecz, w jakim stopniu ta dykcja przemawiała do odbiorców we Francji.

Antologia Kota wywoła zażarty spór, toczyć się on jednak będzie nie w paryskich salonach, a na linii Warszawa - Londyn - Maisons-Laffitte, bo książka zostanie gwałtowanie zaatakowana w Polsce, na łamach wydawanego w Warszawie pisma „Kultura”, nie przypadkiem noszącego tytuł taki sam jak emigracyjny miesięcznik. Wypowiadali się tu Artur Sandauer, przekonując że całe przedsięwzięcie faworyzuje właśnie emigrantów, czy Julian Przyboś, który posunął się do stwierdzenia, iż Wat jest nie tylko słabym poetą, ale też symulantem, leczącym przez lata urojone choroby za pieniądze ludowej Ojczyzny ${ }^{20}$. Czynniki polityczne łączyły się z osobistymi, w końcu jakaż antologia nie wywołała oburzenia tych poetów, którzy czuli się zbyt skromnie w niej reprezentowani, czy krytyków mających własne ambicje tworzenia kanonu. Kot odpowiadał na zarzuty na łamach londyńskich „Kontynentów” ${ }^{21}$, Herbert zaś pocieszał go z Wiednia: „całe nasze nieszczęście, że Ci ludzie o umysłach wysoko wykwalifikowanych korektorów zajmują się literaturą"22. Zapewne pod wpływem tych wydarzeń powstał też zgryźliwy portret Przybosia w cyklu „Pośmiertne życie niektórych polskich poetów”, który autor Hermesa... wysłał Miłoszowi w marcu 1966 roku: „Choć do owada był podobny - sztuk chitynowych mistrz nad mistrze, / Zbawiony został przez pomyłkę, do nieba wśliznął się po nitce. / Przystanął, zadrżał i oniemiał - w kącie walały się gitary. / Nic tu nie było z awangardy: stiuki, kryształy i kotary. / Nie wierzył oczom, którym wierzył. Ujrzał wysiłków

Cyt. za: List Z. Herberta do K. Dedeciusa, bm., bd. [Paryż, 1968]; ZHKD.

Sądząc z listu Olgi Scherer, Herbert zareagował na to dedykując Watowi wiersz, niestety nie wiemy, o jakim utworze mowa: „otrzymałam list od Zbyszka H. z załącznikiem dla Ciebie [...]. Pozwoliłam sobie przeczytać Tobie dedykowany wiersz, który jest piękny. Sądzę, że sprawi Ci nieco radości [...] , zwłaszcza że [...] przypuszczalnie, jak my wszyscy, jesteś przybity wiadomą prozą, która niedawno ukazała się w warszawskiej «Kulturze»" - List O. Scherer do A. Wata, Paryż, 3 lutego 1966; Aleksander Wat Papers, GEN MSS 705, Beinecke Library, Yale University, USA; dalej: AAWBL.

Por.: O „Antologii poezji polskiej": Julian Przyboś, Artur Sandauer, MaciejŻurowski i Janusz Wilhelmi, "Kultura” (Warszawa) 1966 nr 3 oraz K.A. Jeleński Odpowiedź na partyzantkę krytyków, „Kontynenty" (Londyn) 1966 nr 88.

Cyt. za: List K.A. Jeleńskiego do Cz. Miłosza, Paryż, 30 stycznia 1966, w: Cz. Miłosz, K.A. Jeleński Korespondencja, opr. B. Toruńczyk, Zeszyty Literackie, Warszawa 2011, s. 70. 
swych zbyteczność. / I umarł drugi raz. Zupełnie. Tym razem już na całą wiecznośćn"

W porównaniu z wczesnymi latami 50 . był to mimo wszystko pewien postęp, o wydawnictwie przygotowanym przez emigrantów można było w ogóle w Polsce dyskutować, były to jednak dyskusje najczęściej dalekie od obiektywizmu. W kwietniu 1966 roku na łamach „Kultury” by tak rzec: właściwej, czyli paryskiej, napisze więc Czapski z goryczą: „zawsze mi się zdawało, że wśród nas, Polaków, istnieje także ta wyspa poezji, obca szpiclom i cenzorom, że od Miłosza do Ważyka, od Iwaniuka do Herberta czy Przybosia, od Wata do Białoszewskiego jest jedna republika poetów, że po 1956 roku intryga polityczna, szantaż, tej republiki się nie imają. [...] Salwa plutonu egzekucyjnego na rozkaz warszawskiej«Kultury», niski atak na Wata - przekreślają wizję czystej od intryg politycznych wyspy polskiej poezji". ${ }^{4}$

*⿻一𠃋十

Próbą zbudowania takiej wyspy było powołanie pisma literackiego, które wydawane na emigracji drukowałoby także poetów z kraju, umożliwiało wierszom rozmowę ponad granicami, politykę dopuszczało jedynie w wymiarze historiozoficznym, na poziomie np. eseistyki Hannah Arendt, ale też uwalniało środowisko literackie od monopolu paryskiej „Kultury” $i$ jej apodyktycznego szefa. Z początkiem 1966 roku plan takiego almanachu szkicuje Wat w liście do Miłosza, oddając też sytuację garstki pisarzy, nigdy niemogących w pełni utożsamić się ze strategicznymi posunięciami Giedroycia: „jesteśmy wciśnięci pomiędzy obie »Kultury«, ale nasza jest o tyle szlachetniejsza. Trzeba zapomnieć o skłóceniach, małostkowych koniec końców. Gdybyż to Giedroyc nie był taki głupi. Albo tak obłąkany. Albo tak niezłomny. Albo tak megalomański! [...] powinniśmy robić sitwę: Ty, Kot, Józio, Zbyszek, Antoni - masz rację, rola jego moralna ogromna [...]. Zatem: wszyscy za jednego i jeden za wszystkich!"25.

23 Z. Herbert Pośmiertne życie niektórych polskich poetów, w: tegoż Utwory rozproszone. (Rekonesans), opr. R. Krynicki, Wyd. a5, Kraków 2010, s. 234; dalej: WR.

24 J. Czapski Czarny kamień, w: tegoż Rozproszone. Teksty z lat 1925-1988, opr. P. Kądziela, Więź, Warszawa 2005, s. 313.

25 List A. Wata do Cz. Miłosza, 8 lutego 1966, w: A. Wat Korespondencja, cz. I, opr. A. Kowalczykowa, Czytelnik, Warszawa 2005, s. 430. 
Mowa tu była oczywiście o Słonimskim, który w Polsce odgrywał rolę mentora stopniowo krzepnącej opozycji, zaś pismo ostatecznie powstało, choć nie tyle dzięki staraniom Wata, co dlatego że z podobnym zamysłem nosili się Krystyna i Czesław Bednarczykowie, którzy w Londynie ponad dekadę wcześniej stworzyli wydawnictwo o nazwie Oficyna Poetów i Malarzy, dorobili się drukarni, dzięki niej publikowali choćby Norwida, ale też eseje Stempowskiego czy Vincenza, tomy wierszy Brzękowskiego i emigracyjnej "młodzieży” - Iwaniuka, Czaykowskiego, Darowskiego. Ich publikacje wyróżniały się znakomitą szatą graficzną, była to właściwie specjalność Oficyny, z którą współpracowali Feliks Topolski, Franciszka Themersonowa, czasem także Jan Lebenstein. I tak w maju 1966 roku ukaże się pierwszy numer kwartalnika „Oficyna Poetów”, wydawanego w dużym formacie, na świetnym papierze, z grafikami, który istnieć będzie aż do roku 1980, a przez jego łamy przewiną się zarówno najważniejsze nazwiska emigracji, jak i poeci krajowi, wśród nich Różewicz, Barańczak czy Krynicki.

Mimo tych wszystkich autorów londyńskie pismo nie stanie się poważną konkurencją dla „Kultury”, bodaj zbyt artystowskie, pozostające na uboczu historycznych wydarzeń, właściwie podobnie, jak powstała pół roku wcześniej w kraju „Poezja”. Być może po części i dlatego Herbert tu nie publikował, choć samych Bednarczyków poznał i polubił, w liście do Miłosza przekonywał nawet: „właściwie ich kocham. Z panią Bednarczyk nawet przegrałem w ping-ponga, żeby jej zrobić przyjemność"26. Obaj poeci - zapewne obmyśliwszy plan latem 1967 roku, kiedy spotkali się w Prowansji - zamierzali wykorzystać łamy „Oficyny”, by w parodystyczny sposób dać wyraz niechęci do poezji "zjadającej własny ogon", skupiającej się na językowej kunsztowności, metaforyce, dystansującej się zaś wobec codziennego, w tym także politycznego życia. A więc takiej, dopowiedzmy, jaka w Polsce właśnie zaczęła dochodzić do głosu za sprawą grupy o nazwie Orientacja Poetycka Hybrydy, z raczej już zapomnianymi dziś nazwiskami Zbigniewa Jerzyny, Macieja Zenona Bordowicza czy Janusza Żernickiego.

"Hybrydowcy” czuli się pierwszą powojenną formacją wyzwoloną od narodowych czy obywatelskich obowiązków, na początku lat 70. krach tego założenia uprzytomnią im twórcy Nowej Fali. Tymczasem zaś, w połowie 1967 roku Miłosz pisze do Bednarczyka: „o pomyśle «grupy respondystów» nie zapominam - napisałem już cztery wiersze jednego z grupy. Ciśnijcie 
Zbyszka, żeby też pisał"27. Wena mu dopisywała, a walka z nałogiem dodawała wściekłości, bo cztery dni później informuje z kolei Herberta: „respondyści. Napisałem coś pięć wierszy [...]. Wszystko z powodu braku nikotyny. [...] Ściskam Cię, Tudzik"28. Herbert wtedy właśnie docierał do Londynu, więc przynajmniej teoretycznie Bednarczykowie mogli go „cisnąć", ale nie był to dla niego dobry czas na literackie żarty. Choć odpisze, że stworzone przez kolegę teksty przeczytał „w należytym skupieniu. [...] «Wyjaśniam» St. J.Tudzika - słuszne w głównej linii ataku, ale jakoś za mało bezczelne. A w ogóle to się uśmiałem i chciałbym projekt doprowadzić do końca"29, ostatecznie jednak niczego nie stworzy, a jesienią Miłosz z niepokojem raz jeszcze zwróci się do Bednarczyka: „Zbyszek [...] wszystko zawalił. Nie można z nim korespondować. Nie odpowiada. Jeżeli go się nie wyrwie z tego bagna, to zginie. Są jednak jakieś szanse na Amerykę"30.

Do Ameryki Herbert rzeczywiście wyjedzie, natomiast fikcyjna międzynarodowa grupa „respondystów” za życia obu poetów nie ujrzy światła dziennego, w archiwach pozostaną utwory tak arcydzielne, jak choćby Powszechność z liniami: „przyznaj się jak ja się przyznaję / że nie lubisz czytać niczyich wier-

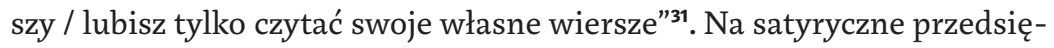
wzięcie miało też wpływ - podzielane przez Herberta i Miłosza - poczucie obcości wobec znacznej części kultury Zachodu, ale główny atak skierowany był w stronę Polski, a to za sprawą manifestu grupy i jego autora, „Stanisława Józefa Tudzika". Wbrew ewentualnym pozorom, zawarte tu obserwacje są całkowicie poważne, Miłosz diagnozuje zasadniczy kryzys sztuki, w komunistycznym państwie łączący się ze strategią popierania tych twórców, którzy programowo zamykają się we własnym światku, są więc z punktu widzenia władzy całkowicie nieszkodliwi. Tak zatem państwo „utrzymuje pewną ilość ludzi których funkcja polega na tym, że wyładowują energię «tworząc», przy czym sama funkcja jest istotna nie produkt - ten jest najczęściej niekomunikatywny, najzupełniej nudny albo niezrozumiały dla odbiorcy. Nic bardziej znamiennego niż miesięcznik «Poezja» i obecność poety Juliana Przybosia

27 List Cz. Miłosza do Cz. Bednarczyka, Berkeley, 13 lipca 1967; Archiwum Oficyny Poetów i Malarzy, Uniwersytet Jagielloński, Kraków; dalej: AOPiM.

List Cz. Miłosza do Zb. Herberta, Berkeley, 17 lipca 1967; ZHCM, 77.

List Zb. Herberta do Cz. Miłosza, Londyn, stempel: 3 sierpnia 1967; ZHCM, 85.

List Cz. Miłosza do Cz. Bednarczyka, Berkeley, 14 listopada 1967; AOPiM.

ZHCM, 79. 
w jego komitecie redakcyjnym. Miesięcznik jest przeznaczony dla poetów którzy w nim publikują swoje wiersze, nie dla czytelników" ${ }^{\prime 2}$. Autor manifestu wskazywał, że trzeba pójść dalej, dać respons na rysujący się kształt przyszłości, tak zatem respondyści otwarcie zakładają, że z ich dzieł „nikt poza samym autorem nie będzie miał przyjemności" ${ }^{\prime 3}$.

Herbert nie dopisał się do tworzonych przez Miłosza tekstów, a szkoda, bo powstałby projekt unikalny, a w dodatku od starszego kolegi miał on bardziej kąśliwe poczucie humoru, co widać choćby w brawurowym szkicu, który z czasem poświęci działalności krytycznoliterackiej Henryka Berezy ${ }^{34}$. Ale w intelektualną tonację zamysłu dokładnie wpisuje się utwór, który został opublikowany na początku lat 70., powstał jednak zapewne wcześniej, dodatkowym impulsem mógł być zresztą Festival dei Due Mondi w Spoleto, na którym poeta gościł ponownie w roku 1969. Jego tytuł brzmi Co myśli Pan Cogito o piekle:

Najniższy krąg piekła. Wbrew powszechnej opinii nie zamieszkują go ani despoci, ani matkobójcy, ani także ci, którzy chodzą za ciałem innych. Jest to azyl artystów, pełen luster, instrumentów i obrazów. Na pierwszy rzut oka najbardziej komfortowy oddział infernalny, bez smoły, ognia i tortur fizycznych.

W tym nieopublikowanym, a powstałym w latach 80. szkicu Herbert miażdżąco wywodził: „na
ostatniej stronie «Twórczości» Henryk Bereza [...] publikuje od lat felieton pod zagadkowym tytułem «Czytane w maszynopisie». Pokorna publika łyka to z nabożeństwem. A przecież jest rzeczą jasną jak słońce, że Bereza mistrzowsko, więcej: genialnie parodiuje styl niektórych meta-krytyków, którzy potrafią pisać o niczym w sposób napuszony i otchłannie głęboki. [...] z niezrównaną maestrią «śmieszy, tumani, przestrasza», wodzi ogłupiałego czytelnika za nos, wymyśla fikcyjnych autorów, obdarza ich hojnie dziełami o komicznych tytułach (na przykład «gigantyczną» - jego słowa - trylogią «W barszczu przygód», «W rosole powikłań», «W krupniku rozstrzygnięć»), a potem pisze o tych widmowych arcydziełach niby-to-recenzje. [...] Mój Boże, co się z tą literaturą ojczystą dzieje? Od trzech pokoleń (z małymi wyjątkami), poezja polska przemawia językiem prostym, jasnym, zdyscyplinowanym. Nie trzeba «znać się na wierszach», żeby zrozumieć co chce i co rzeczywiście komunikuje bliźniemu - Ewa Lipska, Stanisław Barańczak, Ryszard Krynicki. [...] Więc, panie Henryku, proszę grzecznie, niech pan nie przeciąga struny. Chichy chichami, ale żyjemy w czasach poważnych. Czyją wyobraźnię zdolny jest rozpalić cieknący bez ustanku strumień świadomości i to osobników umysłowo poślednich, duchowo nijakich, chociaż nadał im pan imiona tak subtelne i podejrzewam symboliczne jak - «Bubek Dyrdymas», «Lentka Dwupochwowa», czy, excuses le mot -«Piździch»"; AZH, Akc. 17873.

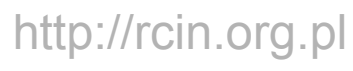


Cały rok odbywają się tu konkursy, festiwale i koncerty. Nie ma pełni sezonu. Pełnia jest permanentna i niemal absolutna. Co kwartał powstają nowe kierunki i nic, jak się zdaje, nie jest w stanie zahamować tryumfalnego pochodu awangardy.

Belzebub kocha sztukę. Chełpi się, że jego chóry, jego poeci i jego malarze przewyższają już prawie niebieskich. Kto ma lepszą sztukę, ma lepszy rząd - to jasne. Niedługo będą się mogli zmierzyć na Festiwalu Dwu Światów. I wtedy zobaczymy, co zostanie z Dantego, Fra Angelico i Bacha.

Belzebub popiera sztukę. Zapewnia swym artystom spokój, dobre wyżywienie i absolutną izolację od piekielnego życia. ${ }^{35}$

W połowie lat 6o. Herbert i Miłosz w sprawach poetyckich całkowicie się ze sobą zgadzają, w pewnym stopniu też współpracują, bo gdy Miłosz przygotowuje antologię Postwar Polish Poetry, Herbert - mający lepszą orientację w tym, co właśnie jest publikowane w kraju - doradza mu, by koniecznie zajrzał do tomu Sól Szymborskiej, pamiętał o wierszach Tadeusza Nowaka, z większym już wahaniem dodając nazwiska Brylla (jak pisze: „na zawoalowaną prośbę autora") czy Mariana Grześczaka ${ }^{36}$. W filipikach przeciwko awangardzie, które obaj pisali, widać zarzut nudnej egocentryczności tego rodzaju pisarstwa, a także braku ciekawości dla losu innych ludzi, co w warunkach państwa opresyjnego nabierało szczególnego znaczenia - nie przypadkiem za kilka lat Herbert zapała sympatią do poetów Nowej Fali, którzy połączą - by posłużyć się tytułem książki Stanisława Barańczaka - etykę z poetyką. Ale jeszcze szerszą kategorią, którą należałoby tu wprowadzić, jest sugestia, że nie tylko polski wiersz, ale całą powstającą współcześnie kulturę drąży zwątpienie, utajona lub jawna rozpacz, która podejrzanie łatwo zamienia się w szyderstwo czy nihilizm.

W listach z tego czasu Herbert aż zaskakująco często składa deklaracje, chce dać świadectwo wartościom, które uznaje za zagrożone. Przywołując jego słynną frazę o poezji, która winna być ocaleniem, pisze do Miłosza: „coraz bardziej jestem pewny tego, że to źródło, które tak łatwo zasypać, bije z powodu pewnych jakości duchowych autora, a nie opanowania techniki czy mistrzostwa języka. Napiszę kiedyś o tym przeciwko bubkom z awangardy.

35 Z. Herbert Co myśli Pan Cogito o piekle, w: tegoż Wiersze zebrane, opr. R. Krynicki, Wyd. a5, Kraków 2008, s. 435. 
Jakości: bezinteresowność, zdolność kontemplacji, wizja utraconego raju, odwaga, dobroć, współczucie, pewna mieszanina rozpaczy i humoru. [...] zgoda ręki z duszą. Myślę, że ja też chciałem w swoich wierszach komuś pomóc (jeśli nie ocalić); i marzyłem o tym, żeby pozostał po mnie jakiś fresk w kościele"37. Gdy zaś zdarzy mu się w Wiedniu obejrzeć Wstręt Romana Polańskiego, z niechęcią skomentuje: „obrzydliwość te trupy w wannie. Ma to być antymieszczańskie, ale to właśnie smak mieszczuchów. [...] Czy nie uważasz, że sztuka powinna pocieszać albo być przynajmniej solidarna z ludźmi, a nie wymyślać nowe rozpacze i makabry"38.

Odrębną jest kwestią, moglibyśmy dodać, czego właściwie chcą owi „ludzie” i czy aby to nie właśnie wtedy rodził się człowiek nam współczesny, którego żadne makabry nie są już w stanie zasmucić. Stefan Chwin napisał kiedyś, co prawda o Miłoszu, ale te trafne słowa, może lekko złagodzone, moglibyśmy również odnieść do Herberta, że „rozpaczy nie chciał i nie umiał w sobie oswoić. Dla nas oswojona rozpacz jest czymś tak zwykłym jak chipsy i guma do żucia. [...] Nie był zdolny do [...] absurdalnego szyderstwa i zwariowanej gry słowami, która dla nas jest czymś tak naturalnym jak powietrze, którym oddychamy" ${ }^{\text {"39 }}$. Oprócz naturalnie najbardziej własnej duchowej konstytucji, był przy tym autor Pana Cogito uczniem Henryka Elzenberga, który niegdyś przepisywał w dzienniku uwagę Pascala: „czyż myślą, że nas tak znów ucieszyli mówiąc nam, że nasze dusze to tylko odrobina wiatru i dymu, i w dodatku mówiąc to głosem pysznym i zadowolonym?”, opatrując ją komentarzem: „nie mogę zarzucać nikomu, że wyznaje pogląd taki lub inny, jeżeli za tym poglądem przemawiają racje poważne. Ale mogę zarzucać, że go wyznaje z radością lub obojętnością, jeśli jest to pogląd śmiertelny dla czegoś, co powinno się cenić" ${ }^{\prime \prime}$.

Otóż Herbert był przekonany i niewątpliwie miał dużo racji, że wielu ze współczesnych mu twórców czy intelektualistów właśnie z obojętnością lub szyderstwem przygląda się, jak umierają wartości takie jak wiara w Boga i nieśmiertelną duszę, sens naszego istnienia, w zapomnienie o sobie w imię wyższych celów, sumienie, grzech i w następującą po nim karę... Właściwie zostawał wykonawcą duchowego testamentu swego mistrza, który zbliżał się do śmierci,

37 List Z. Herberta do Cz. Miłosza, Wiedeń, 17 lutego 1966; ZHCM, 57.

List Z. Herberta do Cz. Miłosza, Wiedeń, 10 grudnia 1965; Czeslaw Milosz Papers, GEN MSS 661, Beinecke Library, Yale University, USA; dalej: ACMBL. 
czego uczeń był świadom, bo ich wspólny znajomy relacjonował mu z Polski: „Elzenberg istotnie umiera [...]. Czyni to z pełną świadomością i godnie, tak jak żył. [...] Jest ciekaw świata, szczególnie zaś kierunku, w którym się on w swoim rozwoju toczy. Czyżby rzeczywiście wbrew jego oczekiwaniom i nadziejom ku całkowitej technicyzacji i dehumanizacji? Głodny jest wszelkich głosów z tego świata, szczególnie od tych, których kocha. A Ciebie kocha, i nie ma wielu takich. Boi się dla Ciebie pisarstwa afektowanego, zmanierowanego i łatwego. Jeśli chcesz i możesz mu wyświadczyć jakieś dobro, pisz do niego często, nawet codziennie. Jeśli nie masz o czym, pisz o rzeczach najpospolitszych, o tym, co robisz, co jesz, co Ci się podoba, a co nie, z kim i o czym rozmawiasz, myślisz, obcujesz... Nie masz pojęcia, jakiego blasku i znaczenia nabierają takie nieistotne zda się rzeczy dla kogoś, kto się żegna z życiem"41.

Herbert nie został pisarzem afektowanym czy zmanierowanym, ale w czasie gdy wiosną 1967 roku Elzenberg zbliżał się do śmierci, on sam wędrował doliną depresji i nie miał sił, by profesorowi wysyłać drobiazgowe korespondencje. Nie zdoła też nigdy ukończyć szkicu na jego temat i dopiero znacznie później, w latach 80., odda mu hołd w wierszu, gdzie znów splotą się różne wątki, raz jeszcze pojawią „wyznawcy nicości”:

Kim stałbym się gdybym Cię nie spotkał - mój Mistrzu Henryku $[\ldots]$

Byłbym do końca życia śmiesznym chłopcem

Który szuka

Zdyszanym małomównym zawstydzonym własnym istnieniem

Chłopcem który nie wie

Żyliśmy w czasach które zaiste były opowieścią idioty

Pełną hałasu i zbrodni

Twoja surowa łagodność delikatna siła

Uczyły jak mam trwać w świecie niby myślący kamień

Cierpliwy obojętny i czuły zarazem

Krążyli wokół Ciebie sofiści i ci którzy myślą młotem

Dialektyczni szalbierze wyznawcy nicości - patrzyłeś na nich

Przez lekko załzawione okulary

Wzrokiem który wybacza i nie powinien wybaczyć

41 List St. Pacuły do Zb. Herberta, Warszawa, 28 października 1966; AZH, Akc. 18005, t. 54. 
Przez całe życie nie mogłem wydobyć z siebie słowa dziękczynienia Jeszcze na łożu śmierci - tak mi mówiono - czekałeś na głos ucznia Którego w mieście sztucznych świateł nad Sekwaną

Dobijały okrutne niańki. ${ }^{42}$

Czasem, gdy przeglądamy archiwa Zbigniewa Herberta, czytamy listy, porównujemy daty, pojawiają się przed nami dni niezwykłe, aż zaskakująco symboliczne. Taki był okres Bożego Narodzenia roku 1966, gdy Herbert siedząc w pokoiku w Antony, zwracał się do dwóch mistrzów swojej młodości, którzy niegdyś reprezentowali dlań filozofię i religię. Wrócił właśnie z Niemiec, a cywilizacja technologicznie coraz sprawniejsza, ale niczym w proroctwach Witkacego zdająca się zapominać o czymkolwiek więcej niż telewizor lub nowy opel, budziła w nim niepokój. Pisze zatem do Elzenberga: „nie mogę odpowiedzieć sobie na pytanie: czy ludzkość zmierza w kierunku zorganizowanego barbarzyństwa"«3 , zaś Jerzego Zawieyskiego zawiadamia, że spędzi Święta „wśród natarczywych maszyn i niezrozumiałej cywilizacji. [...] Piszę coraz cieńsze wiersze i coraz smutniejsze szkice. Bowiem «istotą życia jest zgroza», jak mówi mój umierający Mistrz Elzenberg"44.

Najczęściej w tych latach fundamentalne kwestie porusza jednak w rozmowach z Miłoszem, którego także uważa za - tym razem poetyckiego - mistrza, wielokrotnie mówiąc o tym wprost. „Wczoraj czytałem Twój znakomity szkic o poezji. Uczę się na Tobie ale jestem dość tępy"45 - stwierdzi wkrótce po przyjeździe do Londynu w roku 1963, kiedy mógł nadrobić zaległości w lekturze paryskiej „Kultury”. Oczywiście w takich deklaracjach możemy przeczuwać porcję kokieterii, ale wydaje się, że Herbert szczerze podziwia przyjaciela, a dowody tego uczucia moglibyśmy wpisać do antologii przejawów bezinteresownego zachwytu, o które przecież jednemu artyście wobec dzieł drugiego, w dodatku żyjącego tuż obok, a nie przed wiekami - naprawdę nie jest łatwo. Miłosz też Herberta ceni, w tych latach pracuje nad przekładami jego wierszy, które złożą się na osobny tom, w listach raduje się każdą

42

43

45

44 List Z. Herberta do J. Zawieyskiego, Antony, 23 grudnia 1966, w: Z. Herbert, J. Zawieyski Kore-

Z. Herbert, Do Henryka Elzenberga w stulecie Jego urodzin; WZ, 585.

List Z. Herberta do H. Elzenberga, Antony, 20 grudnia 1966, w: Z. Herbert, H. Elzenberg, "Korespondencja", opr. B. Toruńczyk, Zeszyty Literackie, Warszawa 2002, s. 112; dalej: ZHHE. spondencja 1949-1967, opr. P. Kądziela, Warszawa 2002, s. 144; dalej: ZHJZ.

List Z. Herberta do Cz. Miłosza, Londyn, 3 sierpnia 1963; ZHCM, 25. Być może chodziło o szkic Powikłania jednej porażki opublikowany w „Kulturze” $1963 \mathrm{nr} 4$. 
możliwością spotkania, jest przyjacielski, a czasem ojcowski, ale to młodszy poeta składa wyrazy uwielbienia. W roku 1965 wychodzi tom Gucio zaczarowany, wkrótce dociera do Herberta, a ten opowiada jego autorowi, że książeczkę ma zawsze ze sobą: „czytam w łóżku, tramwaju, wszędzie i nic nie mogę o nim na razie powiedzieć, poza radością jaką mi daje w zadeszczonym Wiedniu. Nawet nie wiesz co znaczy dla mnie czytać Ciebie"46.

Możliwe zresztą, że osiągnięcia poetyckie Miłosza podkreślał szczególnie mocno dlatego, że zdawał sobie sprawę z trudnej emocjonalnie sytuacji, w jakiej znajdował się jego przyjaciel - w Polsce zakazany, praktycznie rzecz biorąc, będący orwellowską non-person, której emigracyjna twórczość bywała często nieznana nawet poetom. Dość zacytować list, jaki do Herberta wysłał Jarosław Marek Rymkiewicz, donosząc, że udało mu się zdobyć wydane przez „Kulturę” zbiory Miłosza. Autor głośnej książki „Czym jest klasycyzm” wyznaje tutaj: „siedzę nad «Traktatem poetyckim». [...] Tym poematem Miłosz dokonał na terenie naszej poezji jakiegoś wyłomu; krok, którego rezultaty są dla nas na pewno nie do przecenienia", rzecz w tym, że ów przełomowy poemat poznawał... piętnaście lat po jego publikacji, na początku lat siedemdziesiątych ${ }^{47}$. Dekadę wcześniej sytuacja była oczywiście gorsza, zaś w Stanach Zjednoczonych, gdzie mieszkał, był Miłosz jednym z tysięcy profesorów, znanym głównie jako autor Zniewolonego umystu, a już niedługo - tłumacz Herberta.

Recenzując Gucia zaczarowanego, Czesław Bednarczyk na łamach „Kontynentów" podkreślał, że jego autor „stał się nauczycielem i mistrzem dla wielu, wielu utalentowanych poetów młodszych i najmłodszych. Jego wypływ dostrzec można u Grochowiaka, Urszuli Kozioł, Śliwonika, Brylla, Iredyńskiego i chyba najwięcej u Herberta [...]. I, o ironio! Herberta obnosimy na ramionach, obsypujemy nagrodami, reprezentuje naszą poezję wśród obcych, a prekursor w tym czasie uczy Amerykanów miłować mowę Polaków”48. Herbert nie tylko się nie zżymał na ten artykuł, ale w liście do przyjaciela deklarował: „Bednarczyk słusznie pisze [...], że jesteś prekursor. Stale mnie to denerwowało, że występuję bez tła, zaplecza i mistrzów, którym tyle zawdzięczam. Czułem się jak hochsztapler. Z całej poezji ostatnich dziesiątków lat tylko trzej poeci mają szansę przetrwania: Ty, Leśmian i Czechowicz. [...]

List Z. Herberta do Cz. Miłosza, Wiedeń, 12 listopada 1965; ZHCM, 50.

47

List J.M. Rymkiewicza do Z. Herberta, Łódź, 5 lutego 1972; AZH, Akc. 18005, t. 61.

Cz. Bednarczyk O „Guciu zaczarowanym”Czesława Miłosza, „Kontynenty” (Londyn) 1965 nr 84. 
jesteś łapczywie czytany, choć nikt się do tego nie przyznaje (z wyjątkiem mnie)" ${ }^{49}$.

Jeśli porównania z Różewiczem zdecydowanie mu ciążyły, to w roli ucznia Miłosza autor Struny światła czuł się - przynajmniej do czasu - najwyraźniej dobrze. Pozwólmy sobie na jeszcze jeden cytat, przede wszystkim dla jego wielkiej urody, ale też po to, aby znów splotły się ze sobą różne pasma. Pod koniec roku 1965 Miłosz ukończył pracę nad poematem zatytułowanym $\mathrm{Na}$ trąbach i na cytrze, który z czasem opublikował w londyńskiej „Oficynie Poetów". Wcześniej jednak wysłał go przyjacielowi, a ten, w Wiedniu otwierał kopertę, zachłannie czytał i następnie ekspediował list do Berkeley:

będzie to poemat-drogowskaz dla polskiej poezji, dzięki swojej bardzo pięknej, męskiej autentycznej postaci. [...] Świetna cała część szósta "opisać chciałem ją, nie inną..." - doświadczałem tego wiele razy, kiedy wysilałem wzrok, żeby zapamiętać las (drzewo po drzewie, liść po liściu), który rozwijał się, kiedy płynąłem przez jezioro Wigry. Kochany, długo krążyłeś jak sęp nad tym poematem i teraz go dopadłeś. Jest w tym ogromna przestrzeń fizyczna i moralna, jakiej nie mają poeci polscy zamknięci w kawiarniach. Jednak emigracja daje nową szerszą perspektywę, chociaż ja po pół roku nieoddychania polskim smrodem czuję się fatalnie.

Dziękuję, że mi przysłałeś. Czytam na głos z gulą w gardle. Moja gospodyni przyzwyczajona do tego że czytam głośno po niemiecku, pytała czy się modlę. Ano modlę się w pewien sposób..$^{50}$

\section{***}

W przywoływanym przed chwilą artykule Czarny kamień Józef Czapski napomykał też, że w przeciwieństwie do dyskutantów z warszawskiej „Kultury” francuscy odbiorcy przyjęli antologię Jeleńskiego bardzo dobrze, ukazało się parędziesiąt pochlebnych recenzji czy przynajmniej wzmianek w gazetach. Trudno dziś ocenić, jakie naprawdę było oddziaływanie tej książki, wiemy natomiast, że jedną z konsekwencji jej powstania było wydarzenie wyjątkowe, jedyne w powojennej polskiej historii oficjalne spotkanie poetów emigracyjnych i tych mieszkających w Polsce, wraz z ich tłumaczami i wydawcami. 
I tak wiosną 1967 roku paryscy czytelnicy pisma „La Quinzaine Littéraire”, które niedawno założył zaprzyjaźniony z Kotem Maurice Nadeau, dowiadywali się, że

dix poètes polonais, avec leurs traducteurs et critiques occidentaux, viennent de participer à un colloque sur les problèmes de la poésie et de la traduction, à Paris, du 1er au 4 mars dernier. Le poète Jarosław Iwaszkiewicz, président de l'Association des Ecrivains polonais, a souligné l'aspect historique de cette rencontre à laquelle participaient pour la première fois ensemble les poètes polonais les plus éminents, qu'ils vivent en Pologne ou à l'étranger. Venus de Pologne, Adam Ważyk, auteur du « Poème pour Adultes », Julian Przyboś, fondateur de l'avant-garde des années 20, Zbigniew Herbert, chef de file de la jeune poésie philosophique, siégèrent à la même table que Jan Brzekowski, Czesław Miłosz, Kasimierz Wierzyński qui vivent à Paris, en Californie ou à Rome, ${ }^{51}$

zaś w ostatnim zdaniu artykuł optymistycznie stwierdzał, że „la poésie polonaise est enfin entrée dans le circuit mondial"'52. Dla równowagi zauważmy, że wspominający to samo spotkanie Jerzy Andrzejewski podkreślał, iż nie było na nim ,telewizyjnych kamer, nawet żaden fotograf się nie zjawił, nikogo z przybyłych nie proszono o wywiady, Październikowa moda na Polskę i polskich intelektualistów i pisarzy już przeminęła”, tak więc polski konwentykl „prasa francuska prawie całkowicie przemilczała"53. Dla Polaków były to jednak dni ważne, zaś jedyną osobą, która w tym czasie mogła wymyślić i zrealizować takie przedsięwzięcie, znaleźć na nie środki, wykorzystać wszystkie prywatne

51 „Dziesięciu polskich poetów ze swoimi tłumaczami i krytykami z Europy Zachodniej przyjechało do Paryża, by uczestniczyć w konferencji na temat problemów poezji i przekładu, trwającej od pierwszego do czwartego marca. Poeta Jarosław Iwaszkiewicz, prezes Związku Literatów Polskich, podkreślił historyczny wymiar tego spotkania, w którym po raz pierwszy uczestniczyli wspólnie najwybitniejsi polscy poeci, żyjący w Polsce lub zagranicą. Pochodzący z Polski Adam Ważyk, autor «Poematu dla dorosłych», Julian Przyboś, prekursor awangardy lat 20., Zbigniew Herbert, lider młodej poezji filozoficznej, usiedli przy jednym stole z Janem Brzękowskim, Czesławem Miłoszem, Kazimierzem Wierzyńskim, mieszkającymi w Paryżu, Kalifornii czy w Rzymie" - przeł. M. Talar.

Polska poezja nareszcie weszła do światowego obiegu - przeł. M. Talar; „Une rencontre de poètes polonais à Paris", ,La Quinzaine Littéraire" (Paris) 1-31 mars 1967.

53 J. Andrzejewski Msza za poetę. (Ustęp początkowy), w: tegoż Nowe opowiadania, Czytelnik, Warszawa 1980, s. 36. 
kontakty, a przy tym wznieść się ponad osobiste sympatie i antypatie - był Jeleński. Dochodziło przynajmniej do próby porozumienia, przekroczenia podziałów zarówno politycznych, jak i estetycznych, budzących zresztą równie wielkie emocje. Kontekst bieżących wydarzeń był przy tym trudny, ponieważ wypowiedzi Juliana Przybosia, które już cytowaliśmy, zdecydowanie nie mieściły się w kategoriach fair-play. Odpoczywający wtedy na Majorce i niemogący wziąć udziału w paryskim spotkaniu, Aleksander Wat tak pisał do Herberta w połowie lutego: „szczerze ubolewam, że nie będę na Zjeździe Poetów Polskich, to jak Zjazd Królów w Erfurcie w roku 1808. Manifestacja jedności poezji polskiej, rzeczywiście bardzo ważna [...] Przyboś z całym sztabem mózgów wypacykował atak na «Antologię» Kota. Poza hultajstwem, wynikającym z niedopieszczenia, doceniam jego głupotę. [...] myślę, że powinien mu dać odpór ktoś z krajowych poetów, żeby jego głos nie uszedł za miarodajny. Ale kto?”. Po czym z precyzją analizował: „na pewno nie Iwaszkiewicz. Może Słonimski? O ile przyjedzie. Nie Ważyk też, bo oni od lat mają milczące porozumienie, aby się wzajemnie oszczędzać. Ty w Twojej trudnej sytuacji nie możesz się wychylać. Ale nie polemizując wprost, można «bawolą brzytewką» (jak mawiał Witkacy) podciąć ichnią znaną przecież argumentację. Poza tym podstępnie szeptaną propagandą izolować go (nienawidzą go przecież wszyscy koledzy)”, by ostatecznie słusznie stwierdzić: „to mało ważne, ważne jest zamanifestowanie jedności poezji polskiej. I moralne zobowiązanie poetów krajowych, żeby wyciągnęli z tego wnioski" ${ }^{44}$.

„Zjazd Królów” odbył się 1-4 marca 1967 roku, oficjalnym dlań pretekstem było ukazanie się aż trzech antologii polskiej poezji, we Francji, Niemczech („Polnische Poesie des 20. Jahrhunderts” Dedeciusa) oraz Stanach Zjednoczonych, ta ostatnia to opracowana przez Miłosza Postwar Polish Poetry. Pomijając już krytyków zagranicznych, np. Alfreda Alvareza, lista polskich twórców, którzy czy to zostali zaproszeni, czy to akurat przebywali wtedy w $\mathrm{Pa}$ ryżu i wzięli w spotkaniu udział, jest imponująca, gdybyśmy mieli odtworzyć stosowną listę obecności, brzmiałaby ona bodaj: Andrzejewski, Bieńkowski, Błoński, Brandys, Brzękowski, Flaszen, Herbert, Iwaszkiewicz, Jastrun, Kwiatkowski, Lisowski, Międzyrzecki, Miłosz, Mrożek, Przyboś, Puzyna, Ważyk, Wierzyński, Wirpsza... Jak z wdziękiem opisywał autor Tanga Leopoldowi Tyrmandowi: widzieć ich wszystkich jednocześnie, „to było piękne, jak

54 List A. Wata do Z. Herberta, bm. [Palma de Mallorca], 10 lutego 1967, w: A. Wat Korespondencja, cz.l, s. $270 \mathrm{in}$. 
widzieć jagnięta i tygrysy zgodnie zaspakajające pragnienie u wodopoju"55. Poruszanie się wśród pięknych okazów literackiej fauny wymagało zdolności dyplomatycznych, czego dowodem jeszcze jeden list Wata, który instruował syna, Andrzeja, mającego przedstawić wystąpienie ojca. Subtelności poczynionych tu rozróżnień nie powstydziłby się dwór Ludwika XV, nic dziwnego też, że najpierw powinna odbyć się próba: „zrób przed wygłoszeniem [...] repetycję - powinno być powiedziane chłodno, ale nie za oschle, niemonotonnie, ale bez aktorstwa”. Potem zaś pojawia się kluczowe pytanie „Jak masz się zachować wobec kolegów z kraju?". Otóż:

z Ważykiem - serdecznie i powiedz mu, że bardzo żałuję, że się z nim nie zobaczę. Z Jastrunem, Brandysem, Bieńkowskim nijako, wobec Iwaszkiewicza - według jego zachowania się. Jeżeli będzie zdawkowy, to i Ty, jeżeli z nutą serdeczną lub żywą niezdawkowo zapyta o mnie, powiedz mu to samo, co Ważykowi, jeżeli będzie konwencjonalny, bądź taki sam. Unikaj, o ile to będzie możliwe, podania ręki Przybosiowi, ale bez żadnej ostentacji. Jeżeli jednak zaatakuje mnie (w co wątpię), wtedy chłodno, z godnością przygotuj sobie parę zdań, mniej więcej: pan Przyboś (możesz z francuska wymówić nazwisko, ale cieniutko, bez przesady) korzysta z nieobecności mego ojca, którego choroba przetrzymuje w Hiszpanii, aby go zaatakować swoim zwyczajem. [...] Jeżeli Przyboś zaatakuje mnie jako grafomana, powiedz, że nie Twoją jest rzeczą polemizować z opiniami pana Przybosia, ale ze względu na uporczywe [...] napaści jego na mego ojca, pozwolę sobie zacytować parę zdań z recenzji wielkiego poety - odczytaj tekst Iwaszkiewicza - i na końcu wymień jego nazwisko jako autora [...]. Ale o ile atak Przybosia będzie w ramach przyzwoitości i zwykłej literackiej polemiki, nie reaguj, natomiast poproś w moim imieniu Herberta, aby skorzystał na tym samym posiedzeniu [...] z okazji wymienienia mojego nazwiska (może między paroma innymi) w sposób pochlebny. ${ }^{56}$

Przebrnąwszy przez te zawiłości, uniknąwszy podania ręki Przybosiowi, mógł już Andrzej Wat głosem niemonotonnym, ale też bez aktorstwa przeczytać esej ojca, który zastanawiał się nad specyfiką przekładania poezji,

55 List Sł. Mrożka do L. Tyrmanda, Chiavari, 7 marca 1967; Leopold Tyrmand Papers, ACC. 86015, Hoover Institution, Stanford University, USA; dalej: LTP.

56 List A. Wata do A. Wata, 22 lutego 1967, w: A. Wat, "Korespondencja”, cz. I, s. 592 i n. 
przypominał fakt istnienia wierszy, których nie sposób oddać trafnie w obcym języku, zauważając przy tym, że „na drugim biegunie [...] są utwory Zbigniewa Herberta, kongenialne we wszystkich trzech językach. Czym to wytłumaczyć: czy ascezą ekspresji Herberta, obywającej się bez magicznych zauroczeń? Czy wysokim stopniem intelektualizacji?" ${ }^{57}$. Ciekawie zauważał, że „polszczyzna jest nade wszystko materią rzeźbiarską, a nie malarską; poeta polski pracuje jak w twardym drzewie czy kamieniu [...] najwłaściwsze są wiersze polskie, w których odczuwa się opór i mękę surowca językowego", czego dowodem geniusz Norwida. Szkodzi zaś tym wierszom dziedzictwo

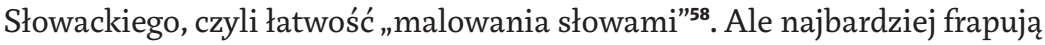
myślowe korespondencje z Herbertem, bo jeśli autor Struny światła pisał do Miłosza o tym, że źródłem poezji są wartości inne niż elastyczność języka, to Wat szukał kryterium pozwalającego ocenić autentyczność wiersza i dochodził do wniosku, że jest nim rzecz „spoza walorów estetyki. Mianowicie właściwość moralna: szczerość; właściwość psychologiczno-biograficzna: twarz poetycka, to znaczy poetycka osobowość (odróżnić od osobowości poety) oraz los. Także właściwość metafizyczna, wyczuwalna: cena, którą poeta płaci sobą [...] za każdy wiersz"59.

On sam za każdy wiersz płacił wielką ceną, to samo zresztą moglibyśmy powiedzieć o Herbercie, którego Jeleński, otwierając kolejne posiedzenie „zjazdu" przedstawiał jako dziś „najlepiej znanego za granicą polskiego poetę": , ,amerykańscy poeci walczący z wojną w Wietnamie widzą w nim brata, młodzi angielscy i niemieccy poeci Nowej Lewicy poświęcają mu wiersze", zaś Thomas Merton twierdzi, że autor Trenu Fortynbrasa ,jest jednym z najważniejszych poetów naszej epoki"60.

Herbert z pewnością lepiej by się czuł, gdyby mógł jedynie przeczytać kilka swoich wierszy, może opatrzyć je krótkim komentarzem, zwłaszcza że miał już tekst taki gotowy, niedawno znakomicie sprawdził się podczas festiwalu w Berlinie. Ale Kot prosił go o wygłoszenie referatu o związkach między poezją angielską i polską, zapewne nie podejrzewając, że dostarczy przyjacielowi sporo udręk, gdyż nie była to materia, którą lubił on podejmować. „Nic

\footnotetext{
57 A. Wat O nieprzekładalności utworów poetyckich, w: tegoż Publicystyka, opr. P. Pietrych, Czytelnik, Warszawa 2008, s. 619.

58 Tamże, s. 625.

59 Tamże, s. 629.

60 K.A. Jeleński Zbigniew Herbert przeł. M. Ochab, „Zeszyty Literackie” jesień 1999 nr 68.
} 
się na tym nie znam"61 - oceniał z dozą przesady w liście do londyńskich przyjaciół, Czajkowskich, a do Zdzisława Najdera ekspediował ekspresową pocztą prośbę o pomoc. Ten zaś odpowiadał: „wpadłem w lekki popłoch na widok tematu tej arii, którą masz odśpiewać. [...] Tak czy inaczej, na miejscu w Paryżu będzie Cię podtrzymywał Miłosz"62. Następnie spisywał uwagi o tym, jak w Polsce tłumaczono i interpretowano Eliota, które zresztą może bardziej miały przyjaciela wesprzeć niż dostarczyć mu informacji, wszakże autora Jałowej ziemi Herbert czytał od dawna, ba - uznawał za autorytet. Ale w marcu 1967 roku, gdy powoli wychodził z psychicznej zapaści, publiczne wystąpienie było dlań męką. Po latach wspomni w liście do Iwaszkiewicza z wdzięcznością: „matkowałeś mi w Paryżu, kiedy wygłaszałem żałosny referacik [...] (było wówczas ze mną źle)"63.

Referacik ów, zapewne lepiej przyjęty przez odbiorców, niż oceniał to autor, dotrwał do naszych czasów jedynie we francuskim przekładzie ${ }^{64}$, zapewne Kota lub Teresy Dzieduszyckiej, znów zatem musimy przywrócić polszczyźnie myśli Herberta, na wstępie zastrzegającego, że jako mówca czuje się tym razem niezręcznie, powinien go raczej zastąpić krytyk lub tłumacz. Wskazuje jednak, że to właśnie anglojęzyczna poezja od parudziesięciu lat budzi szczególnie duże zainteresowanie polskich czytelników i twórców, a do powstania takiej sytuacji nie wystarczą żadne mechanizmy administracyjne, konieczna jest duchowa potrzeba. Ona właśnie zdecydowała, że Eliot - nieśmiało przekładany i komentowany jeszcze w dwudziestoleciu międzywojennym - po wojnie stał się istotnym punktem odniesienia dla polskich twórców. Horror okupacji kierował bowiem naszą literaturę w stronę utartych ścieżek sentymentalizmu i tradycjonalizmu, na co lekarstwem mogła być jedynie postawa stoicka, „oderwanie się poety od jego osobistych doświadczeń", przedstawianie ich „w szerszym historycznym kontekście”. I tu właśnie pojawia się myśl Eliota o poezji niebędącej ekspresją emocji, a próbą ich kamuflowania i obiektywizowania. „Kiedy istniały jeszcze odrębne nurty i grupy

61 List Z. Herberta do M. i Z. Czajkowskich, Paryż, 2 lutego 1967, w: Herbert i „Kochane Zwierzqtka”. Listy zebrała i komentarzem opatrzyła Magdalena Czajkowska, Rosner i Wspólnicy, Warszawa 2006, s. 113; dalej: ZHKZ.

List Z. Najdera do Z. Herberta, Berkeley, 2 lutego 1967; AZH, Akc. 17987, t. 1.

63 List Z. Herberta do J. Iwaszkiewicza, Warszawa, 29 listopada 1971, w: Z. Herbert, J. Iwaszkiewicz Listy, "Zeszyty Literackie" nr 84 (jesień 2003).

64 Francuski tekst wystąpienia Z. Herberta udostępniony autorowi książki przez Henryka Citko. Przekład polski: A.M. Migdał. 
literackie, jak symbolizm czy surrealizm, było łatwiej śledzić linie wpływu. [...] Za naszych czasów [...] trzeba się zadowolić wydobyciem pewnych ogólnych tendencji, przejawiających się dziś w poezji polskiej, a trochę wcześniej w anglosaskiej" - mówił dalej. Tendencje te to intelektualizacja wiersza, nieledwie nieobecność autora, tworzenie masek, postaci, dzięki czemu „poezja liryczna zbliża się do dramatu". Przyznawał wreszcie autor Hermesa..., że twórca polski „zaznajamiający się z poezją angielską i amerykańską może dostać zawrotu głowy wobec ich bogactwa", kusi go zatem ucieczka, tymczasem postawą twórczą jest dążenie do spotkania, nawet jeśli będzie ono natrafieniem na „przeciwników, którzy niszczą nasz spokój i poczucie bezpieczeństwa, ale za to pobudzają do stawiania oporu, lepszego zrozumienia nas samych".

Te kilka paryskich marcowych dni miało atmosferę niezwykłą zwłaszcza dla twórców emigracyjnych, przyzwyczajonych do samotności, postawionych poza naturalnym im środowiskiem, z codziennymi spotkaniami, dyskusjami, żartami. „Można sobie wyobrazić ilość przyjęć, kolacji, koktajlów etc., zatrącających o «Wesele» Wyspiańskiego. Wynikiem u mnie jest na razie ból brzucha [...]. Ale za to ugadałem się po uszy"65 - relacjonował Miłosz Bednarczykom, najpełniej jednak te chwile sportretował dwa lata później Andrzejewski, wplatając opowieść o nich do poświęconego Kazimierzowi Wierzyńskiemu opowiadania Msza za poetę. Przeczytamy tutaj, że

konferencje [...] odbywały się w godzinach popołudniowych, w małej auli w solidnym i ciężkim gmachu, na wprost kościoła St. Germain des Prés. W Paryżu, o każdej porze roku, a także dnia i nocy, nietrudno spotkać Polaka, szczególnie na St. Germain, wówczas jednak [...] zagęszczenie polskości w tej dzielnicy było wyjątkowe, mały odcinek bulwaru z narożnym, jarmarcznym „Drug Storem” i Lippem, a z „Deux Magots” i z »Café de Flore po stronie przeciwnej, ten zawsze gwarny i zatłoczony deptak interesów, przeróżnych snobizmów oraz płatnej, głodnej miłości sprawiał niekiedy wrażenie, jakby na skutek magicznych ruchów pałeczki Prospera, który stał się polskim patriotą, wielojęzyczny tłum Francuzów, Niemców,

65 List Cz. Miłosza do Cz. i K. Bednarczyków, Paryż, 9 marca 1967, cyt. za: G. Fijas Korespondencja Czesława Miłosza z Oficyną Poetów i Malarzy 1963-1973. Edycja krytyczna, praca magisterska napisana pod kierunkiem prof. J. Gruchały, Uniwersytet Jagielloński, Wydział Polonistyki, Kraków 2016, s. 120. 
Anglików, Amerykanów i Włochów nagle zastygł, a wszelki ruch życia, mowa i widzenie pozostawione zostały jedynie polskim poetom. ${ }^{66}$

Po koktajlu, który w swojej galerii na Wyspie Świętego Ludwika wydali Romanowiczowie, późnym już wieczorem Andrzejewski wraz z Miłoszem i jego żoną, Janką, Ważykiem, Lebensteinem i Olgą Scherer znaleźli niedrogą knajpkę, a w niej stolik przy oknie. Zamówili karafki czerwonego wina i patrzyli jak

na wybrzeżu zapaliły się gazowe latarnie, jedna zaraz za naszym oknem, i wówczas, gdy tak ciasno stłoczeni siedzieliśmy i popijaliśmy wino, zaczęło się dziać coś z teatru i także trochę ze snu: tuż za szybą, w poblasku latarni z mgły, która nad rzeką i na wybrzeżu zdążyła zgęstnieć, wyłaniały się, wolno przechodziły i jak cienie znów w mgle znikały pary przed chwilą zagubionych: Wierzyński z Iwaszkiewiczem, Przyboś i Brzękowski, Józef Czapski z Arturem, Herbert i Maciek Morawski...67

66 J. Andrzejewski Msza za poetę, s. 37.

67 Tamże, s. 49. 


\section{Abstract}

\section{Andrzej Franaszek}

PEDAGOGICAL UNIVERSITY OF CRACOW

A Congress of Kings: Zbigniew Herbert in the Polish Paris of 1967

The year 1967 saw an unprecedented event in Paris: Polish poets, both from Poland and from the diaspora, came together with translators from France, Germany and the USA. The congress was organized by the émigré critic and essayist Konstanty Jeleński. Among the participants was Zbigniew Herbert, who had settled near Paris. This was a key moment in postwar Polish literary history as well as in Herbert's life, as he was going through the nervous breakdown that would weigh over him for the rest of his life. This article, a contribution to the poet's biography, portrays these moments as well as Herbert's friendship with Aleksander Wat.

\section{Keywords}

Zbigniew Herbert, Aleksander Wat, Konstanty Jeleński, Jerzy Andrzejewski, Polish diaspora in France in the 1960s, congress of Polish poets and translators in Paris in 1967 